\title{
Effects of animal size and nutritional status on the RNA/DNA ratio in different tissues of the green-lipped mussel Perna viridis
}

\author{
JAMIUS W.Y. YEUNG AND KENNETH M.Y. LEUNG \\ The Swire Institute of Marine Science and School of Biological Sciences, the University of Hong Kong, Pokfulam, Hong Kong, \\ People's Republic of China
}

\begin{abstract}
This study aimed to examine the responses of RNA/DNA ratio in Perna viridis under different nutritional status via both field and laboratory studies, and hence evaluate the usefulness of this ratio as a rapid growth biomarker in the mussels. First, the effects of size (small: 30-40 mm; medium: 40-50 mm; large: $>50 \mathrm{~mm}$ ) and tissue type (adductor muscle, foot, gill and hepatopancreas) on the RNA/DNA ratio were investigated in $\mathrm{P}$. viridis collected from three different sites with different degrees of eutrophication in Hong Kong waters. Across all sizes, the mussels collected from a fairly 'eutrophic' mariculture zone had significantly higher RNA/DNA ratios in their gills than those from the other two relatively clean sites. The RNA/DNA ratio in small mussels was generally higher than in medium and large individuals, though such a size effect significantly interacted with tissue type and site. Second, we conducted a 10-day comparative laboratory study to elucidate the influence of starvation and feeding on the RNA/DNA ratio in the mussels. We observed that both hepatopancreas and foot muscle generally exhibited significant and rapid response to such a short-term starvation or food addition. The present results confirmed that the RNA/DNA ratio in P. viridis is a sensitive biomarker to gauge their growth and general health condition in accordance with food availability and/or eutrophication condition.
\end{abstract}

Keywords: RNA/DNA ratio, Perna viridis, biomonitoring, biomarker, eutrophication, mussel

Submitted 2 March 2011; accepted 27 July 2011; first published online 17 October 2011

\section{INTRDDUCTION}

Mussels inhabiting the natural environment are subjected to the changes in food availability (Wong \& Cheung, 2001) which eventually effect their growth and health condition (Menge et al., 2007). In South-east Asia, the green-lipped mussel, Perna viridis (Linnaeus, 1758), plays an important role in molluscan culture by serving as an abundant and cheap protein source in this region (Menzel, 1988; Chou \& Lee, 1997; Rajagopal et al., 1998; Wong \& Cheung, 2001). Regular growth and health assessment would be necessary for quality assurance in the mussel farming industry. Although physiological responses, such as change in biomass and condition index, have been used for assessing growth and health condition in bivalves (Widdows, 1978), the responses usually required a longer exposure duration to reveal measurable effects. Recently, the nucleic acid ratio between RNA content and DNA content in tissues (i.e. RNA/DNA ratio) has been proposed as an efficient index for evaluation of the general health condition of marine organisms when exposed to rapidly changing natural and anthropogenic stressors (Dahlhoff \& Menge, 1996; Wo et al., 1999; Yang et al., 2002; Dahlhoff, 2004). The RNA/ DNA ratio has demonstrated its versatile utility in assessing growth rate and condition of fish (Buckley, 1979) and

Corresponding author:

K.M.Y. Leung

Email: kmyleung@hku.hk subsequently other marine organisms such as bivalves (Menge et al., 2007), copepods (Wagner et al., 1998) and crustaceans (Moss, 1994).

Previous studies have reported that the RNA/DNA ratio is a sensitive biomarker to food availability in different species (Parslow-Williams et al., 2001; Okumura et al., 2002; Speekmann et al., 2006). However, the intrinsic biological variations, such as size and tissue types, could mask the response in the RNA/DNA due to food availability (Mayrand et al., 1994; Norkko \& Thrush, 2006). Therefore, the present study involved both field and laboratory aspects to examine the effects of endogenous factors (animal size and tissue types) and food availability on the RNA/DNA ratio of $P$. viridis. The results would provide a sound basis for more accurate interpretation of the RNA/DNA ratio when it is adopted as a rapid growth biomarker in $P$. viridis cultured in the mussel farming industry or used in a biomonitoring programme for marine pollution.

\section{MATERIALS AND METHODS}

\section{Field study}

Various sizes of the green-lipped mussel Perna viridis were collected from three sites in Hong Kong, namely Hoi Ha Wan (HHW), Bluff Island (BI) and Lamma Island (LI), between September and October 2008 (Table 1; Figure 1); LI is located within a mariculture zone. Mussels at HHW and 
Table 1. General hydrographical and geographical information of the three study sites.

\begin{tabular}{|c|c|c|c|c|c|}
\hline Site & $\begin{array}{l}\text { Geographical } \\
\text { coordinate }\end{array}$ & Water zone & Nutrient gradient & Human activities & References \\
\hline Hoi Ha Wan & $22^{\circ} 28^{\prime} \mathrm{N} 114^{\circ} 19^{\prime} \mathrm{E}$ & $\begin{array}{l}\text { Tolo Harbour and } \\
\text { Channel }\end{array}$ & Oligotrophic/mesotrophic & $\begin{array}{l}\text { Marine park with coral } \\
\text { protection area nearby }\end{array}$ & $\begin{array}{l}\text { Chau, 2007; } \\
\quad \text { Miao et al., } 2006\end{array}$ \\
\hline Bluff Island & $22^{\circ} 19^{\prime} \mathrm{N} 114^{\circ} 11^{\prime} \mathrm{E}$ & $\begin{array}{l}\text { Mirs Bay water control } \\
\text { zone }\end{array}$ & Oligotrophic & Coral protection area & Wu et al., 2003 \\
\hline Lamma Island & $22^{\circ} 11^{\prime} \mathrm{N} 114^{\circ} 7^{\prime} \mathrm{E}$ & $\begin{array}{l}\text { Southern water control } \\
\text { zone }\end{array}$ & Eutrophic & Aquaculture & $\begin{array}{l}\text { Liu et al., 2000; } \\
\text { Lee et al., } 2005\end{array}$ \\
\hline
\end{tabular}

BI were found attaching to the submerged chain of floating buoys near a coral protection area, while those collected from LI were attached to the raft of an open-sea-cage fish farm where nutritional fish feed in the form of pellet or trash fish were commonly applied. To verify if RNA/DNA ratios of mussels collected from these three different sites (i.e. HHW, BI and LI) were influenced by the degree of nutrient enrichment, secondary water quality monitoring data on the nutrient enrichment related parameters including turbidity, volatile suspended solids, total inorganic nitrogen, chlorophyll- $a$ and total suspended solids were extracted from the Marine Water Quality Database (2004-2007) of the Environmental Protection Department (EPD) of the Hong Kong Special Administrative Region Government (HKEPD, 2008). As there were three, two and two marine water sampling stations for LI, BI and HHW, respectively, all available data for each of the three sites were pooled for statistical comparison.

No significant difference in salinity, temperature and dissolved oxygen levels was found among the study sites during the sampling period. All collected mussels were transported to the laboratory in a cool box with ambient seawater. Upon arrival at the laboratory, any epibiotic organisms on the mussel shells were removed. To investigate the effect of animal size on the RNA/DNA ratio, mussels were divided into three size-classes, 30-40 mm (small), 40-50 mm (medium) and $>50 \mathrm{~mm}$ (large), according to the shell length measured with calipers (accuracy: $\pm 0.5 \mathrm{~mm}$ ). For each size-class, 15 mussels were randomly selected from each sampling location. Adductor muscle (AD), foot, gill and hepatopancreas (HP) were excised and weighed from each mussel and snap frozen in liquid nitrogen in an autoclaved microcentrifuge tube. Frozen samples were stored at $-80^{\circ} \mathrm{C}$ until nucleic acid analysis.

\section{Laboratory study}

To investigate the effect of nutritional status (i.e. starving versus feeding) on the RNA/DNA ratio, mussels with initial shell length of $30-40 \mathrm{~mm}$ were collected from HHW and used for the laboratory experiment. As a previous study has demonstrated that the RNA/DNA ratio in marine mussels can be influenced by size and vary significantly between different sites (Norkko et al., 2006), this study was restricted to Perna viridis with a similar size (i.e. shell length) collected from HHW only. This size-range was chosen based on the results of the above field study and previous literature showing that small immature mussels generally exhibited the highest RNA/DNA ratio in their tissues when compared with the larger mature mussels and provided a more sensitive

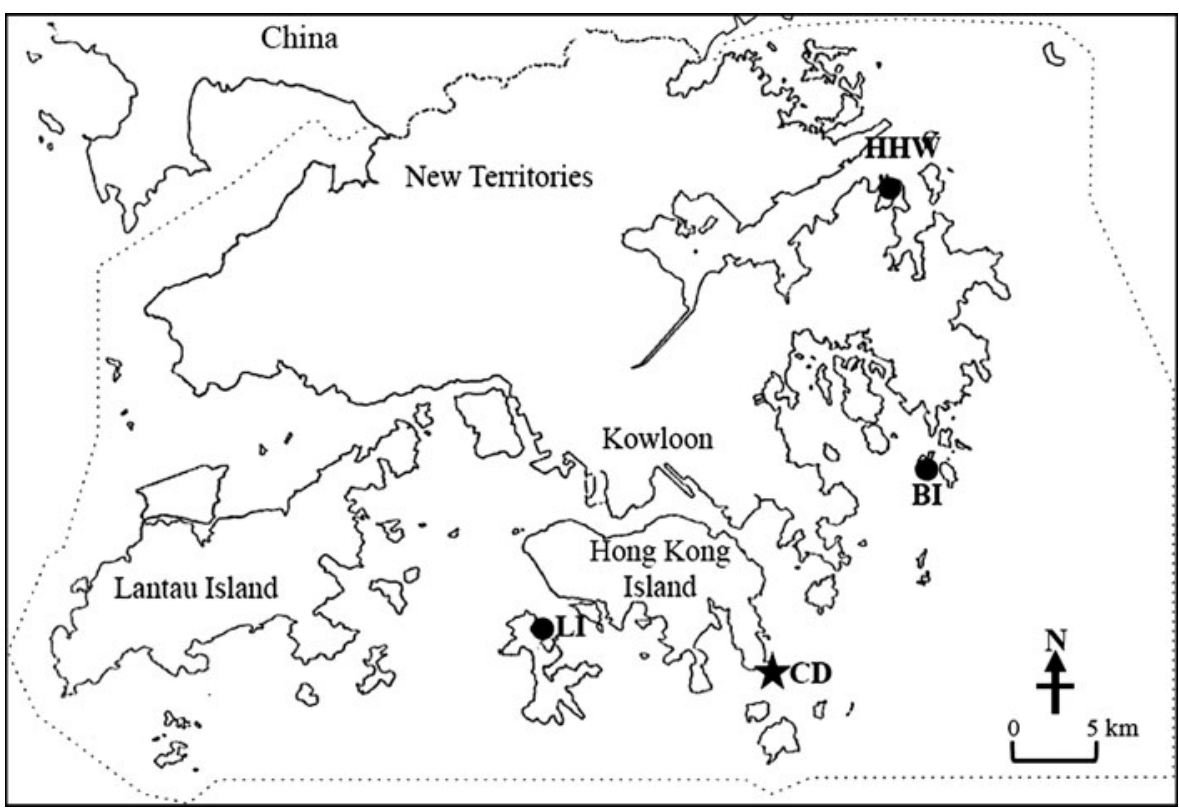

Fig. 1. Map of Hong Kong showing the sampling sites where the mussels Perna viridis were collected at Hoi Ha Wan (HHW), Bluff Island (BI) and Lamma Island (LI), respectively. A filled star indicates the location of the Cape D'Aguilar Marine Reserve (CD) where natural seawater was taken, filtered and used for the laboratory study. 
response in terms of the magnitude of change to the ambient environment (Chícharo \& Chícharo, 2008). Any epibiotic organisms on the mussel shells were removed. The mussels were then acclimated to laboratory conditions (salinity at $33 \%$ ( $\pm 2 ; \pm S D)$, temperature at $\left.25^{\circ} \mathrm{C}( \pm 1)\right)$ for 2 weeks before experimentation. During the acclimation period, the level of dissolved oxygen was maintained at $>90 \%$ saturation with running natural seawater from the Cape D'Aguilar Marine Reserve (CD: $22^{\circ} 11^{\prime} \mathrm{N} 114^{\circ} 13^{\prime} \mathrm{E}$; Figure 1); the mussels were initially starved for the first week and then fed with the marine microalgae Tetraselmis spp. in the second week. After the acclimation period, 25 mussels were randomly selected and allocated to each of the two experimental treatments (i.e. starving versus feeding). In the starving treatment, the mussels were placed in an 81 glass tank filled with membrane filtered seawater (Millipore $0.22 \mu \mathrm{m}$ membrane, Billerica, MA, USA) collected from Cape D'Aguilar Marine Reserve and were not fed with the marine microalgae for 10 days. In the feeding treatment, mussels were placed in the same condition as the starved mussels except that they were provided with Tetraselmis spp. at a density of $5 \times 10^{6}$ cells/ $\mathrm{ml}$ on a daily basis. The ration concentration was comparable with the cell density observed during algal bloom in the eastern waters of Hong Kong (Yung et al., 1997; Wong \& Wong, 2009). The experimental conditions were maintained at $12 \mathrm{~h}: 12 \mathrm{~h}$ light:dark cycle, salinity at $33 \%$ o $( \pm 2 ; \pm \mathrm{SD}), \mathrm{pH}$ at $8.7( \pm 1)$, temperature at $25^{\circ} \mathrm{C}( \pm 1)$ and dissolved oxygen level $>90 \%$ saturation through aeration. Water was renewed once every two days. The exposure duration of 10 days was chosen as the endpoint, based on the results of a pilot study where mortality was observed in starved mussels after 10 days. Five mussels were randomly collected from each treatment tank by the end of Day 10 and $\mathrm{AD}$, foot, gill and HP of each selected mussel were dissected and stored at $-80^{\circ} \mathrm{C}$ until the nucleic acid analysis.

\section{Nucleic acid analysis}

The fluorometric method was used to measure the concentration of nucleic acids while extraction and quantifying procedures followed those described by Caldarone et al. (2001) with some modifications. In brief, a sample of snap frozen tissues was homogenized by Ultra Turrax homogenizer (IKE Werke, Germany) in $200 \mu \mathrm{l}$ of $1 \%$ STEB ( $1 \mathrm{~g} \mathrm{~N}$-sarcosil in $100 \mathrm{ml} 1 \times$ TE buffer) in $1.5 \mathrm{ml}$ microcentrifuge tube. The homogenate was then shaken at $4{ }^{\circ} \mathrm{C}$ for 1 hour. After shaking, $1 \mathrm{ml} 1 \times \mathrm{TE}$ buffer was added to the homogenate and mixed thoroughly by vortex or mechanical inversion for 40 times. This made up the final concentration of the mixture with $0.2 \%$ STEB. The mixture was then centrifuged at $10,000 \mathrm{rpm}$ for 30 minutes. To avoid the re-suspension of tissue particulates, $1 \mathrm{ml}$ of supernatant was transferred to an autoclaved microcentrifuge tube for storage at $-80^{\circ} \mathrm{C}$ before analysis.

Upon analysis, $75 \mu \mathrm{l}$ of the supernatant was loaded to a well of a 96-well plate and $75 \mu \mathrm{l}$ of ethidium bromide fluorescence was added to the supernatant. After 30 minutes, fluorescence of total nucleic acid was measured using the spectrofluorometer with a microplate reader (M2e, Molecular Devices Corporation, USA) and the SOFTmax Pro. 5.1. software (Molecular Devices Corporation, USA) at $525 \mathrm{~nm}$ excitation wavelength and $590 \mathrm{~nm}$ emission wavelength. After the first fluorescence measurements, $7.5 \mu \mathrm{l}$
RNase of $200 \mu \mathrm{g} / \mathrm{ml}$ was added and 45 -minute incubation time was followed to ensure that all the RNA was hydrolysed by the enzyme. The fluorescence was subsequently measured as above for the second reading. In essence, RNA fluorescence values were the difference between the first and second fluorescence readings; and DNA fluorescence values were the second fluorescence reading. RNA and DNA concentrations in the samples were determined from the standard calibration curves which were constructed by running the same analysis with standards of known DNA and RNA contents (Sigma calf thymus DNA, $1.5-15 \mu \mathrm{g} / \mathrm{ml}$; Sigma calf liver RNA, Type IV, 5-40 $\mu \mathrm{g} / \mathrm{ml})$.

\section{Statistical analyses}

Levene's test was used to test for homogeneity of variance of the RNA/DNA ratio among treatment groups and the results indicated that all treatment groups shared an equal variance for the field study but not for the laboratory study. To correct the heterogeneity of variance, datasets from the laboratory study were log-transformed. For the field study, a 3-way analysis of variance (ANOVA) was used to test the variation in the RNA/DNA ratio in field collected mussels among sites (3 levels: BI, HHW and LI), animal sizes (3 levels: small, medium and large) and tissue types (4 levels: $\mathrm{AD}$, foot, gill and HP), while all three factors were treated as fixed factors. For the laboratory study, a 3-way ANOVA was used to compare the log-transformed RNA/DNA ratios among the four tissue types ( $\mathrm{AD}$, foot, gill and $\mathrm{HP}$ ), two time points (Day o versus Day 10) and the two feeding treatments (starving versus feeding). For ANOVA, a post-hoc Student-Newman-Keuls (SNK) multiple comparison test was used to identify any significantly different means. A multivariate analysis of variance (MANOVA) was used to verify if there was site difference in the nutrient enrichment related parameters measured by Hong Kong Environmental Protection Department (HKEPD, 2008) with a post-hoc SNK test to identify any significantly different means. Spearman's correlation analyses were performed on the mean values of environmental parameters and RNA/DNA ratios of different tissues from field collected mussels. All data analyses were performed using SPSS (Version 17.0, Chicago, IL, USA).

\section{RESULTS}

\section{Field study}

The RNA/DNA ratio of Perna viridis varied significantly between the three sites, four tissue types and three size-classes, and these factors also significantly interacted with each other (Table 2; Figure 2), though the effects of tissue type and site were more apparent than the influence of size as indicated by the $\mathrm{F}$ value of each fixed factor (Table 2). In AD, RNA/ DNA ratios were similar among all size-groups for each of the three sites while both medium and large mussels collected from BI had a significantly lower RNA/DNA ratio than those from LI and HHW (Figure 2A). The RNA/DNA ratio in foot muscles of the small BI mussels was significantly higher than that in the medium animals (Figure $2 \mathrm{~B}$ ), whereas RNA/DNA ratios in foot muscles of mussels collected from HHW and LI were fairly similar across all size-classes (Figure 2B). 
Table 2. Results of 3-way analysis of variance of RNA/DNA ratio of four tissues (adductor muscle, foot, gill and hepatopancreas) from three sizeclasses (small, medium and large) of Perna viridis collected from three sampling sites (Hoi Ha Wan, Bluff Island and Lamma Island). Bold $P$ values indicate factors with significant effect at $P<0.05$.

\begin{tabular}{lrrlrrr}
\hline Factor & \multicolumn{1}{l}{ SS } & df & MS & \multicolumn{1}{l}{ F } & \multicolumn{1}{l}{ P } & Power \\
\hline Site & 7.797 & 2 & 3.898 & 38.063 & $<\mathbf{0 . 0 0 0 1}$ & 1.000 \\
Tissues & 13.144 & 3 & 4.381 & 42.776 & $<\mathbf{0 . 0 0 0 1}$ & 1.000 \\
Size & 1.219 & 2 & 0.610 & 5.952 & $\mathbf{0 . 0 0 2 8}$ & 0.879 \\
Site $\times$ tissues & 7.025 & 6 & 1.171 & 11.431 & $<\mathbf{0 . 0 0 0 1}$ & 1.000 \\
Site $\times$ size & 2.488 & 4 & 0.622 & 6.073 & $<\mathbf{0 . 0 0 0 1}$ & 0.987 \\
Tissues $\times$ size & 0.340 & 6 & 0.057 & 0.553 & 0.7679 & 0.223 \\
Site $\times$ tissues $\times$ size & 2.420 & 12 & 0.202 & 1.969 & $\mathbf{0 . 0 2 5 2}$ & 0.919 \\
Error & 50.187 & 490 & 0.102 & & & \\
Total & 466.752 & 526 & & & & \\
\hline
\end{tabular}

Irrespective of size and site effects, RNA/DNA ratios of the gills of $P$. viridis were significantly and consistently lower than those measured in other tissues (Figure 2). There was a significant and consistent site effect on the RNA/DNA ratio in the gills across all size-classes with LI mussels having the highest ratio, BI mussels being the intermediate and followed by those from HHW (Figure $2 \mathrm{C}$ ). Nonetheless, effect of size on $\mathrm{RNA} / \mathrm{DNA}$ ratios in the gills was insignificant (Figure $2 \mathrm{C}$ ).
Variation of RNA/DNA ratios of HP was site specific; size effect was statistically significant in HHW mussels only in which the RNA/DNA ratio decreased with increasing size (Figure 2D; Table 2). In general, mussels of all size-classes from $\mathrm{BI}$ consistently showed the lowest RNA/DNA ratio in all tissue types except the gills when compared with that of the other two sites (Figure 2D)

\section{Spatial variation in nutrient-related parameters}

Based on the HKEPD data (Table 3), waters nearby LI consistently showed significantly higher values for all of the nutrient enrichment related parameters when compared with those measured nearby BI and HHW (Table 4). These results suggested that there was considerably higher nutrient levels and greater food availability (as reflected by chlorophyll- $a$ ) to filter feeding Perna viridis in LI than in the other two sites.

Spearman's correlation analyses, however, revealed significant positive correlations between the mean RNA/DNA ratios of $\mathrm{AD}$, gill and HP tissues, and the averages of nutrient-related environmental parameters (Table 5). Specifically, the mean RNA/DNA ratios in both $\mathrm{AD}$ and $\mathrm{HP}$ were positively correlated with turbidity and chlorophyll- $a$ concentration,

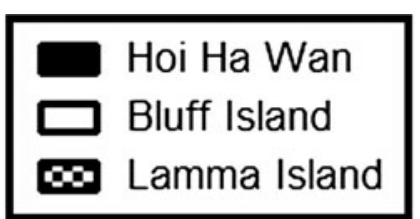

A

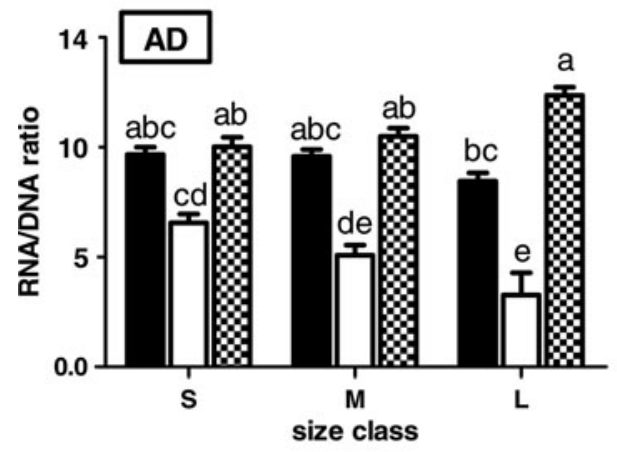

C

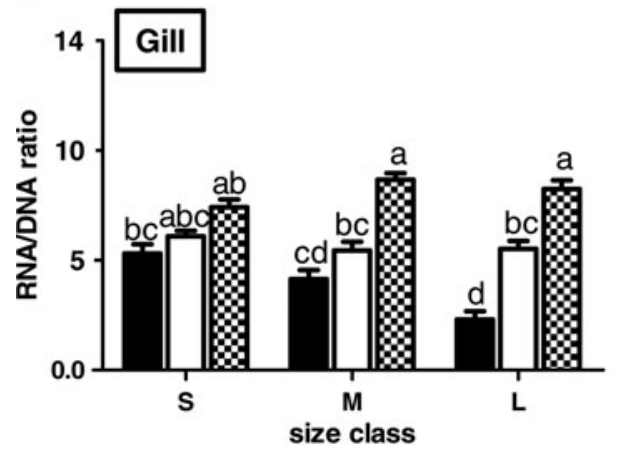

B

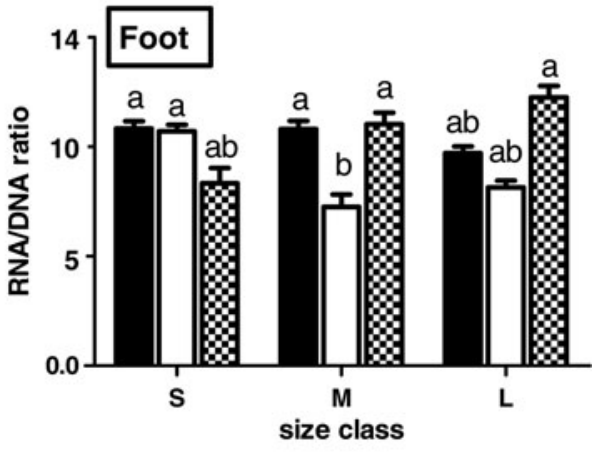

D

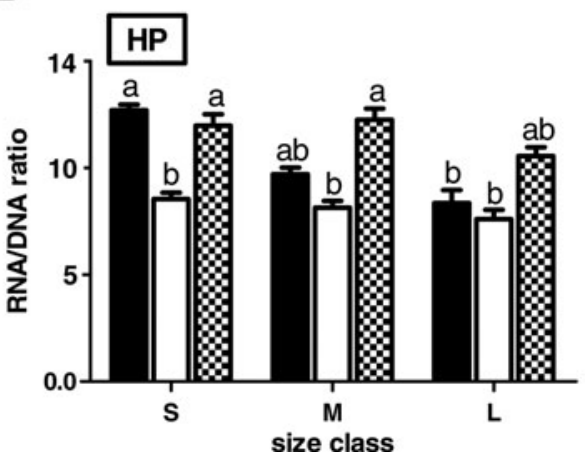

Fig. 2. Mean RNA/DNA ratios ( $+\mathrm{SEM}, \mathrm{N}=13-15)$ in the four tissue types (A) adductor muscle (AD), (B) foot, $(C)$ gill and (D) hepatopancreas (HP) in three different size-classes (i.e. S, small, 30-40 mm; M, medium, 40-50 mm; and L, large, $>50 \mathrm{~mm}$ ) of Perna viridis collected from three different sampling sites including Hoi Ha Wan, Bluff Island and Lamma Island. Bars labelled with different letters indicate significantly different means at $P<0.05$ (StudentNewman - Keuls test). 
Table 3. Environmental data from sampling sites in this study (mean \pm SEM). Data were collected from the Marine Water Quality Database (2004- 2007) of the Environmental Protection Department (EPD) of Hong Kong Special Administrative Region Government (HKEPD, 2008).

\begin{tabular}{llllllll}
\hline Site & $\begin{array}{l}\text { Sampling station } \\
\text { by EPD }\end{array}$ & Depth & $\begin{array}{l}\text { Turbidity } \\
\text { (nephelometric } \\
\text { turbidity units) }\end{array}$ & $\begin{array}{l}\text { Volatile } \\
\text { suspended } \\
\text { solids }(\mathbf{m g} / \mathbf{l})\end{array}$ & $\begin{array}{l}\text { Total inorganic } \\
\text { nitrogen }(\mathbf{m g} / \mathbf{l})\end{array}$ & $\begin{array}{l}\text { Chlorophyll- } \boldsymbol{a} \\
(\boldsymbol{\mu g} / \mathbf{l})\end{array}$ & $\begin{array}{l}\text { Suspended } \\
\text { solids }(\mathbf{m g} / \mathbf{l})\end{array}$ \\
\hline Lamma Island & $\mathrm{SM}_{3}, \mathrm{SM}_{4}, \mathrm{SM}_{5}$ & Middle water* & $10.30 \pm 4.39$ & $1.60 \pm 0.78$ & $0.15 \pm 0.10$ & $3.27 \pm 4.05$ & $3.99 \pm 2.86$ \\
Bluff Island & $\mathrm{PM}_{11}, \mathrm{MM} 14$ & Middle water* & $8.48 \pm 3.20$ & $0.54 \pm 0.58$ & $0.06 \pm 0.04$ & $1.83 \pm 2.30$ & $1.90 \pm 2.11$ \\
Hoi Ha Wan & MM17, MM6 & Middle water* & $8.49 \pm 3.86$ & $0.45 \pm 0.53$ & $0.05 \pm 0.04$ & $2.41 \pm 2.38$ & $1.59 \pm 1.71$ \\
\hline
\end{tabular}

*Notes: according to the marine water quality report from Hong Kong Environmental Protection Department (HKEPD, 2008), 'middle water' is defined as the water column between $1 \mathrm{~m}$ below sea surface and $1 \mathrm{~m}$ above seabed.

Table 4. Results of multivariate analyses of variance on nutrient-related environmental variables of three sampling sites (Lamma Island (LI); Bluff Island (BI); Hoi Ha Wan (HHW)) from HKEPD data between 2004 and 2007 (HKEPD, 2008). Factors with significant effect at $P<0.05$ are indicated by bold $P$ values.

\begin{tabular}{|c|c|c|c|c|c|c|}
\hline Factor & Variables & df & MS & $\mathbf{F}$ & $P$ & Student-Newman-Keuls test \\
\hline \multirow[t]{5}{*}{ Site } & Turbidity (NTU) & 2 & 135.112 & 8.756 & $<0.0001$ & $\mathrm{LI}>\mathrm{BI}=\mathrm{HH}$ \\
\hline & Volatile suspended solids $(\mathrm{mg} / \mathrm{l})$ & 2 & 13.463 & 30.650 & $<0.0001$ & \\
\hline & Total inorganic nitrogen (mg/l) & 2 & 0.375 & 69.494 & $<0.0001$ & \\
\hline & Chlorophyll- $a(\mu \mathrm{g} / \mathrm{l})$ & 2 & 62.480 & 6.149 & 0.002 & \\
\hline & Suspended solids (mg/l) & 2 & 209.830 & $37 \cdot 347$ & $<0.0001$ & \\
\hline \multirow[t]{5}{*}{ Error } & Turbidity (NTU) & 333 & 15.432 & & & \\
\hline & Volatile suspended solids (mg/l) & 333 & 0.439 & & & \\
\hline & Total inorganic nitrogen $(\mathrm{mg} / \mathrm{l})$ & 333 & 0.005 & & & \\
\hline & Chlorophyll- $a(\mu \mathrm{g} / \mathrm{l})$ & 333 & 10.162 & & & \\
\hline & Suspended solids (mg/l) & 333 & 5.618 & & & \\
\hline
\end{tabular}

NTU, nephelometric turbidity units.

respectively; whereas the mean $\mathrm{RNA} / \mathrm{DNA}$ ratios of gill were positively correlated with volatile suspended solid, total inorganic nitrogen and suspended solids, respectively. Surprisingly, none of the environmental parameters showed a significant correlation with the mean RNA/DNA ratios in gill tissues (Table 5).

\section{Laboratory feeding experiment}

No mortality of $P$. viridis was observed throughout the experiment. This experiment primarily tested the hypothesis that differences in food availability (i.e. starved versus fed mussels) could influence the RNA/DNA ratio in their tissues. In general, RNA/DNA ratios of starved mussels were significantly lower than those in fed mussels at the end of experimentation after ten days (Figure 3 \& Table 6; ANOVA: $\mathrm{F}_{1,47}=4.849, P=0.033$ ), but the magnitude of change in the ratio greatly varied among different tissue types (ANOVA: $\mathrm{F}_{3,47}=6.321, P=0.001$ ).

RNA/DNA ratios of AD between starved and Day o mussels were quite consistent, while the difference between starved and fed mussels on Day 10 was significant (Figure 3; Table 6; SNK test: $P<0.05)$. The coefficients of variation $(\mathrm{CV})$ in the ratios of $\mathrm{AD}$ were found to be $26 \%$ and $<40 \%$ for starved and fed mussels, respectively. Foot muscle exhibited the most significant difference between starved and fed mussels in which the mean ratios of fed mussels were significantly higher than those in starved mussels (Figure 3; Table 6; SNK test; $P<0.05$ ). However, a high variability in RNA/DNA ratios of foot muscle was noted as reflected by the CV $(>67 \%$ for fed mussels and $>80 \%$ for starved ones). In gills, RNA/DNA ratios of fed and starved mussels were fairly stable $(\mathrm{CV}<$ $35 \%$ for both starved and fed mussels) during the experimental period (Figure 3; Table 6; SNK test: $P>0.05$ ).

Irrespective of food availability, RNA/DNA ratios of the gills were generally lower among all tissue types (Figure 3). This observation was consistent with those observed in the field experiment. Similar to the foot muscle, RNA/DNA ratios of $\mathrm{HP}$ in fed mussels $(\mathrm{CV}=45 \%)$ were significantly higher than those in starved mussels $(\mathrm{CV}=51 \%)$ and slightly higher than the ratio initially measured on Day o (Figure 3; Table 6; SNK test: $P<0.05$ ).

\section{DISCUSSIDN}

It has been widely suggested that the RNA/DNA ratio in sessile marine organisms may be a useful biomarker in coastal habitats that are constantly fluctuating in food dynamic, and changes in magnitude of the RNA/DNA ratio are often representative of the ambient condition (Chícharo et al., 2001; Dahlhoff et al., 2002; Dahlhoff, 2004; Norkko et al., 2005). Before making proper use of this biomarker, the background of natural variability in their responses needs to be better understood. The current results demonstrated that the RNA/DNA ratio varied significantly among sites with different levels of nutrient enrichment, among tissue types and to a lesser extent among different size-classes. Our observations have provided useful background information on the use of the RNA/DNA ratio as a growth (or stress) biomarker in the mussel farming industry or a biomonitoring programme for marine pollution. 
Table 5. Results of Spearman's correlation analyses on the relationships between RNA/DNA ratios of different tissues (i.e. AD, adductor muscle; foot; gill; HP, hepatopancreas) in field collected Perna viridis and nutrient-related environmental parameters $(\mathrm{N}=9)$.

\begin{tabular}{|c|c|c|c|c|c|}
\hline Tissue & $\begin{array}{l}\text { Turbidity } \\
\text { (nephelometric } \\
\text { turbidity units) }\end{array}$ & $\begin{array}{l}\text { Volatile suspended } \\
\text { solids }(\mathrm{mg} / \mathrm{l})\end{array}$ & $\begin{array}{l}\text { Total inorganic } \\
\text { nitrogen }(\mathrm{mg} / \mathrm{l})\end{array}$ & $\begin{array}{l}\text { Chlorophyll-a } \\
(\mu \mathrm{g} / \mathrm{l})\end{array}$ & $\begin{array}{l}\text { Suspended } \\
\text { solids }(\mathrm{mg} / \mathrm{l})\end{array}$ \\
\hline \multicolumn{6}{|l|}{$\mathrm{AD}$} \\
\hline${ }^{*} r_{\mathrm{s}}$ & $0.949^{* *}$ & 0.474 & 0.474 & $0.949^{* *}$ & 0.474 \\
\hline$P$ & $<0.001$ & 0.197 & 0.197 & $<0.001$ & 0.197 \\
\hline \multicolumn{6}{|l|}{ Foot } \\
\hline$r_{\mathrm{s}}$ & 0.211 & -0.053 & -0.053 & 0.211 & -0.053 \\
\hline$P$ & 0.586 & 0.893 & 0.893 & 0.586 & 0.893 \\
\hline \multicolumn{6}{|l|}{ Gill } \\
\hline$r_{\mathrm{s}}$ & 0.474 & $0.949^{* *}$ & $0.949^{* *}$ & 0.474 & $0.949^{* *}$ \\
\hline$P$ & 0.197 & $<0.001$ & $<0.001$ & 0.197 & $<0.001$ \\
\hline \multicolumn{6}{|l|}{ HP } \\
\hline$r_{\mathrm{s}}$ & $0.738^{*}$ & 0.211 & 0.211 & $0.738^{*}$ & 0.211 \\
\hline$P$ & 0.023 & 0.586 & 0.586 & 0.023 & 0.586 \\
\hline
\end{tabular}

${ }^{*} r_{\mathrm{s}}$, Spearman's correlation coefficient. ${ }^{*} P<0.05 ;{ }^{* *} P<0.001$.

\section{Food availability and RNA/DNA ratio}

It is a well-known fact that there is a strong link between coastal food availability and mussel physiology (Dahlhoff \& Menge, 1996). The results from the present field and laboratory studies supported this postulation and confirmed that the level of the RNA/DNA ratio in the mussel is tissue-specific and can reflect nutritional status (well-fed versus starvation), which is directly related to food availability. Mussels collected from BI always had significantly lower RNA/DNA ratios in $\mathrm{HP}$, adductor and foot muscles than mussels collected from LI and HHW, while there was a consistent spatial variation of the ratio in the gills (i.e. LI $>$ BI $>$ HHW). Such observed spatial variations in the RNA/DNA ratio could be partially attributed to the difference in nutrient-related hydrographical condition among sites. For instance, BI is located in the southeastern waters of Hong Kong subjected to inputs from the oligotrophic South China Sea (Wu et al., 2003) with relatively limited freshwater and nutrient input (e.g. nitrogen and silicon) from terrestrial runoff (Miao et al., 2006; HKEPD,

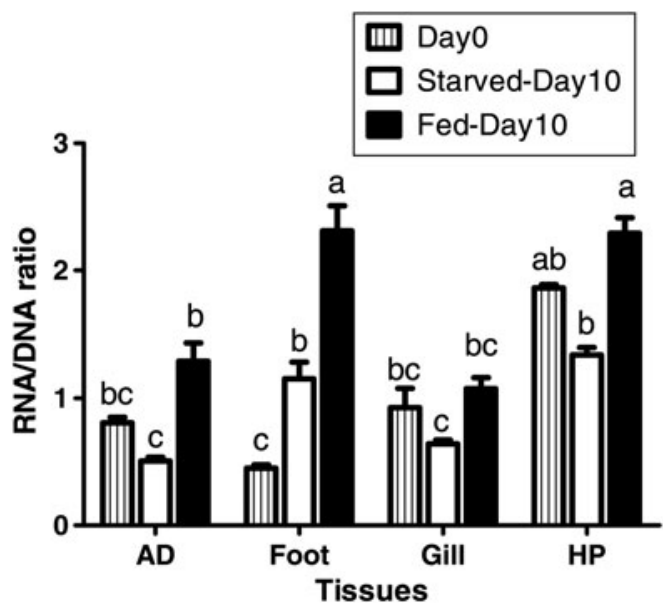

Fig. 3. Mean RNA/DNA ratios (mean $+\mathrm{SEM}, \mathrm{N}=5$ ) in different tissues, adductor muscle (AD), foot, gill and hepatopancreas (HP), between fed and starved Perna viridis after the 10-day experimental period. Black bars represent fed mussels, whereas white bars represent starved mussels. Bars with vertical line represent reference mussels on Day o. Bars labelled with different letters indicate significantly different means at $P<0.05$ (StudentNewman-Keuls test).
2008). Under such a low nutrient condition, mussels at BI would have comparatively lower food availability, slower growth rate and hence a lower RNA/DNA ratio in contrast to those living in the eutrophic LI site.

On the contrary, high RNA/DNA ratios were frequently registered in LI mussels, especially in the gills, where there appears to be the most 'eutrophic' environment among the three study sites because there were significantly higher concentrations of nutrient-related parameters in the water column (HKEPD, 2008). Mussels from LI were, in fact, situated at an open-sea-cage fish farm where fish meals (in the form of pellets) and minced trash fish with high protein content are commonly applied as fish feed (Rumsey 1993). Any unconsumed fish food and fish faecal egestion can accumulate as organic matter on the seabed which can be re-suspended in the water column to serve as additional nutrient supply for filter feeding mussels to promote their growth (Hylland et al., 1996; Leung et al., 1999) and result in elevated RNA/DNA ratios in the mussels (Norkko et al., 2006). Conceivably, the RNA/DNA ratio in mussels could be used as a sensitive biomarker to differentiate sites with different levels of nutrient enrichment.

The present laboratory experiment was designed to test the hypothesis that the RNA/DNA ratio decreases with starvation in the mussel. This is an important consideration for inferring mussel's metabolic activity in the field while the results would be useful to evaluate the sensitivity of different tissues towards poor nutritional status in terms of the RNA/DNA ratio. After starving for ten days, Perna viridis showed a significant decrease in RNA/DNA ratios in $\mathrm{AD}, \mathrm{HP}$ and gill tissues when compared with the fed individuals. On the contrary, the RNA/DNA ratio of foot muscles was still elevated in the mussels even under starvation. Such an increase in the amount of RNA abundance may be associated with the continuous synthesis of proteinaceous byssus threads required for settlement on substrate, irrespective of food availability or energy supply (Shin et al., 2002; Wang et al., 2010). By comparing between starved and well-fed mussels, RNA/ $\mathrm{DNA}$ ratios in foot muscle, $\mathrm{HP}$ and $\mathrm{AD}$ were very sensitive to a short-term change in food availability (i.e. 10 days) and such results reinforce the findings obtained in the field study (as discussed above). Like P. viridis, previous studies also reported that starvation can result in reduced RNA/DNA 
Table 6. Results of 3-way analysis of variance on RNA/DNA ratios in four different tissues of fed and starved Perna viridis (i.e. 2 feeding treatments) over the 10-day experiment experimental period (i.e. 2 time points: Day o versus Day 10). Factors with significant effects at $P<0.05$ are indicated by bold $P$ values.

\begin{tabular}{|c|c|c|c|c|c|c|}
\hline Factor & SS & df & MS & $\mathbf{F}$ & $P$ & Power \\
\hline Feeding treatment & 2.629 & 1 & 2.629 & 4.849 & 0.033 & 0.578 \\
\hline Time & 1.513 & 1 & 1.513 & 2.791 & 0.101 & 0.373 \\
\hline Tissues & 10.280 & 3 & 3.427 & 6.321 & 0.001 & 0.953 \\
\hline Feeding treatment $\times$ time & 2.629 & 1 & 2.629 & 4.849 & 0.033 & 0.578 \\
\hline Feeding treatment $\times$ tissue & 0.248 & 3 & 0.083 & 0.152 & 0.928 & 0.076 \\
\hline Time $\times$ tissues & 4.688 & 3 & 1.563 & 2.882 & 0.046 & 0.652 \\
\hline Feeding treatment $\times$ time $\times$ tissues & 0.248 & 3 & 0.083 & 0.152 & 0.928 & 0.076 \\
\hline Error & 25.479 & 47 & 0.542 & & & \\
\hline Total & 136.338 & 63 & & & & \\
\hline
\end{tabular}

ratios in bivalves (Wright \& Hetzel, 1985; Dahlhoff et al., 2002), gastropods (Okumura et al., 2002) and fish (Ferron \& Legett, 1994). The decrease in the RNA/DNA ratio is related to the reduction or inhibition of protein synthesis and thus the ratio can be used as an indication of hindered growth and metabolism (Dahlhoff, 2004; Chícharo \& Chícharo, 2008). Thereby, the lower RNA/DNA ratio may signify the slow growth rate (or poor health, i.e. stress condition) in the mussels that are perhaps under deprived food availability coupled with other physical-chemical stresses.

\section{Size effect on RNA/DNA ratio}

It is a general physiological rule that juvenile animals usually have a higher metabolic rate and faster growth (Chícharo \& Chícharo, 2008). As such, one would predict that small mussels should present a higher RNA/DNA ratio reflecting a high rate of protein synthesis for somatic growth (Hawkins, 1991). This study, however, did not show and support the hypothesized size-dependent trend that the RNA/DNA ratio increases with decreasing size in Perna viridis. Instead, the current results showed that the size effect on the RNA/DNA ratio in $P$. viridis is highly tissue-specific and site-specific. Thus, it is not possible to make tangible generalizations on the size effect. The size effect was only significant in $\mathrm{AD}$ and foot muscle of BI mussels and in gill and HP of HHW mussels, in which small mussels exhibited a higher RNA/ DNA ratio than in medium and large mussels (Figure 2). Referring to the HKEPD data, BI and HHW are relatively 'oligotrophic'. The decline of RNA/DNA ratios with increasing size observed in BI and HHW mussels could be the combined consequence due to the limited exogenous food available and the allocation of endogenous energy reserves from somatic growth to reproduction (Roddick et al., 1999; Mouneyrac et al., 2008). Also, it should be noted that a decrease in the RNA/DNA ratio with increasing age most likely reflects a decrease in growth rate but may not necessarily indicate a decrease in condition (Chícharo \& Chícharo, 2008).

The discrepancy of the size effect between sites is probably associated with the better nutritional status in LI mussels contrasting with BI and HHW mussels. The elevated food availability associated with fish farming activities might have promoted fast growth and thus overridden the size effect on RNA/DNA ratios in LI mussels. Norkko et al. (2006) also reported a similar observation that the effect of enhanced food availability could override the negative effect of hypoxia on the RNA concentration in marine benthic bivalves.
Moreover, it has been reported that there were significant differences in nucleic acid concentration between males and females of marine organisms during the spawning season (Chícharo \& Chícharo, 2008). The current study did not take gender effect into account, as it was not possible to identify the sex of Perna viridis solely based on the colour of the gonad without in-depth histological studies (Lee, 1988). Based on the field study conducted by Cheung (1991), P. viridis in Hong Kong exhibited year-round spawning and thus gender effect might influence the interpretation of the RNA/DNA ratio to a certain extent. However, several studies also elucidated that food availability is the primary controlling factor for growth and gonad development in mussels (Sreenivasan et al., 1989; Rajagopal et al., 2006). Hence, gender and size could be comparatively minor factors influencing the result and interpretation of the RNA/DNA ratio in the mussels under eutrophic condition. A further study on the gender effect on the ratio in $P$. viridis is still needed to verify this postulation.

Nonetheless, the current results did show that small mussels in two sites (BI and HHW) exhibited the highest RNA/DNA ratio in most cases. Therefore, selecting small fast-growing individuals for measurement of the RNA/DNA ratio is still preferable as it may provide a more sensitive response (in terms of the magnitude) to the change of ambient levels of nutrients and toxicants.

\section{Sensitivity of RNA/DNA ratio in different tissues due to food availability}

In the present field study, the correlation analyses demonstrated that the level of the RNA/DNA ratio, particularly in $\mathrm{HP}, \mathrm{AD}$ and gill tissues of the mussels, is strongly associated with nutrient levels in the marine environment. In our laboratory study, RNA/DNA ratios of $\mathrm{HP}, \mathrm{AD}$ and gill tissues of the mussels considerably reduced after starvation for ten days, while feeding could promote the elevation of the ratio in all tissues, in particular more pronounced increases were observed in foot muscle and $\mathrm{HP}$ tissues. RNA/DNA ratios of HP and foot are comparatively more sensitive to nutritional status because they are characterized by dynamic protein-based activities, but in different aspects.

Hepatopancreas serves as an energy storage organ to allocate energy utilization among tissues (Mayrand et al., 1994; Segnini de Bravo, 2003). The increase in the RNA/DNA ratio of HP is more directly related to energy acquisition and facilitated growth. HP consists of digestive glands which produce digestive enzymes and also act as a buffer organ to store and distribute metabolites to other parts of the organism (Pease, 1976; 
Mayrand et al., 1994). Since HP is actively involved in the metabolic and enzymatic activities, a higher rate of protein turnover is expected (Bayne et al., 1976) and this is reflected in our results that HP tissues have a significantly higher RNA/DNA ratio over other tissue types in most of the cases.

As mentioned above, a high RNA/DNA ratio in foot muscles of $P$. viridis is probably related to the secretion of proteinaceous byssal threads (Coan et al., 2000). Under a desirable environmental condition, mussels are more likely to attach on the substratum by pressing foot muscles firmly on the surface and secreting adhesive protein for byssus production (Nishida et al., 2003) and lead to elevated RNA/DNA ratio. Given that there was high variation (shown by the coefficient of variation) in the RNA/DNA ratios in foot muscle and no significant correlation between the ratio in this tissue and all of the nutrient-related environmental parameters, the RNA/DNA ratio of foot muscle may be less directly related to the energy acquisition or nutritional associated factors. Wang et al. (2010) proposed that byssus thread production has to compete with other physiological processes for energy which may reduce the tolerance of the mussels to stress, and consequently inhibit the chance of their survival. However, the present laboratory study was a short-term experiment in which survival was not threatened by energy depletion. It would be worthwhile and interesting to further investigate the potential energetic trade-off between byssus production and survival under prolonged starvation when growth becomes negative.

\section{CONCLUSION}

To summarize, the RNA/DNA ratio in the mussel Perna viridis, particularly in HP tissues, is sensitive to nutritional-related stresses. Spatial or temporal comparison of the ratio between different groups of $P$. viridis should be carried out by selecting the appropriate types of tissues and to a lesser extent a confined size-class for analysis. Although RNA/DNA ratios of $\mathrm{AD}$ and gill tissues were relatively less sensitive to short-term changes in food availability in the laboratory experiment, their ratios in field collected mussels displayed a clear spatial variation pattern corroborated by the difference in nutrient-related hydrographical condition in a more long-term time scale. Given that considerable differences in the RNA/DNA ratio were found between tissue types, conversion factors could also be estimated and adopted to facilitate the comparison between studies using different tissues of the same species for nucleic acid analysis (Olivar et al., 2009). By choosing suitable tissues at a confined size of the same population of $P$. viridis (e.g. 30-40 $\mathrm{mm}$ in shell length) with optimum sample size, the RNA/DNA ratio could be a useful biomarker for indicating the cellular growth of the mussels and indirectly reflecting the propensity of primary productivity in the marine ecosystem.

\section{ACKNOWLEDGEMENTS}

This work is partially supported by the Area of Excellence Scheme under the University Grants Committee of the Hong Kong SAR Government (project no. AoE/P-04/2004). We thank Dr Vivien Bao for proofreading an early draft of this paper. Jamius Yeung thanks the Swire Institute of Marine Science and the University of Hong Kong for providing her with a postgraduate studentship.

\section{REFERENCES}

Bayne B.L., Widdows J. and Thompson R.J. (1976) Physiology I. In Bayne B.L. (ed.) Marine mussels: their ecology and physiology. Cambridge: Cambridge University Press, pp. 121-159.

Buckley L.J. (1979) Relationships between RNA-DNA ratio, prey density, and growth rate in Atlantic cod (Gadus morhua) larvae. Journal of the Fisheries Research Board of Canada 36, 1497-1502.

Caldarone E.M., Wagner M., St Onge-Burns J. and Buckley L.J. (2001) Protocol and guide for estimating nucleic acids in larval fish using a fluorescence microplate reader. Northeast Fisheries Science Center Reference Document 1-11, 1-22.

Chau K.W. (2007) Integrated water quality management in Tolo Harbour, Hong Kong: a case study. Journal of Cleaner Production 15, 1568-1572.

Cheung S.G. (1991) Energetics of transplanted populations of the greenlipped mussel Perna viridis (Linnaeus) (Bivalvia: Mytilacea) in Hong Kong. I: growth, condition and reproduction. Asian Marine Biology 8, $117-131$.

Chícharo L.M.Z., Chícharo M.A., Alves F., Amaral A., Pereira A. and Regala J. (2001) Diel variation of the RNA/DNA ratios in Crassostrea angulata (Lamarck) and Ruditapes decussatus (Linnaeus 1758) (Mollusca: Bivalvia). Journal of Experimental Marine Biology and Ecology 259, 121-129.

Chícharo M.A. and Chícharo L. (2008) RNA:DNA ratio and other nucleic acid derived indices in marine ecology. International Journal of Molecular Sciences 9, 1453-1471.

Chou R. and Lee H.B. (1997) Commercial marine fish farming in Singapore. Aquaculture Research 28, 767-776.

Coan E.V., Scott P.V. and Bernard F.R. (2000) Bivalve seashells of western North America. Santa Barbara, CA: Santa Barbara Museum of Natural History.

Dahlhoff E.P. (2004) Biochemical indicators of stress and metabolism: applications for marine ecological studies. Annual Review of Physiology 66, 183-207.

Dahlhoff E.P. and Menge B.A. (1996) Influence of phytoplankton concentration and wave exposure on the ecophysiology of Mytilus californianus. Marine Ecology Progress Series 144, 97-107.

Dahlhoff E.P., Stillman J.H. and Menge B.A. (2002) Physiological community ecology: variation in metabolic activity of ecologically important rocky intertidal invertebrates along environmental gradients. Integrative and Comparative Biology 42, 862-871.

Ferron A. and Leggett W.C. (1994) An appraisal of condition measures for marine fish larvae. Advances in Marine Biology 30, 217-303.

Hawkins A.J.S. (1991) Protein turnover: a functional appraisal. Functional Ecology 5, 222-233.

HKEPD (Hong Kong Environmental Protection Department) (2008) Marine water quality data. Government of Hong Kong Special Administrative Region (2009). Available online at http://epic.epd. gov.hk/ca/uid/marinehistorical/p/1 (accessed 31 December 2009).

Hylland K., Skold M., Gunnarsson J.S. and Skei J. (1996) Interactions between eutrophication and contaminants. IV. Effects on sedimentdwelling organisms. Marine Pollution Bulletin 33, 90-99.

Lee S.Y. (1988) The reproductive cycle and sexuality of the green mussel Perna viridis (L.) (Bivalvia: Mytilacea) in Victoria Harbour, Hong Kong. Journal of Molluscan Studies 54, 317-323.

Lee J.H.W., Hodgkiss I.J., Wong K.T.M. and Lam I.H.Y. (2005) Real time observations of coastal algal blooms by an early warning system. Estuarine, Coastal and Shelf Science 65, 172-190.

Leung K.M.Y., Chu J.C.W. and Wu R.S.S. (1999) Nitrogen budgets for the areolated grouper Epinephelus areolatus (Forskål) cultured under 
laboratory conditions and in open sea cages. Marine Ecology Progress Series $186,271-281$.

Liu J.H., Kueh C.S.W. and Broom M.J. (2000) Phytoplankton population dynamics, nutrient changes and red tides in the southern waters of Hong Kong. Asian Marine Biology 17, 137-147.

Mayrand E., Pellerin-Massicotte J. and Vincent B. (1994) Small scale variation of biochemical indices of growth in Mya arenaria (L.). Journal of Shellfish Research 13, 199-205.

Menge B.A., Daley B.A., Sanford E., Dahlhoff E.P. and Lubchenco J. (2007) Mussel zonation in New Zealand: an integrative ecophysiological approach. Marine Ecology Progress Series 345, 123-140.

Menzel W. (1988) Mussel culture in China. Journal of Shellfish Research 7 , 569-570.

Miao A.J., Hutchins D.A., Yin K., Fu F.X., Harrison P.J. and Wang W.X. (2006) Macronutrient and iron limitation of phytoplankton growth in Hong Kong coastal waters. Marine Ecology Progress Series 318, 141-152.

Moss S.M. (1994) Growth rates, nucleic acid concentrations, and RNA/ DNA ratios of juvenile white shrimp, Penaeus vannamei boone, fed different algal diets. Journal of Experimental Marine Biology and Ecology 182, 193-204.

Mouneyrac C., Linot S., Amiard J-C., Amiard-Triquet C., Métais I., Durou C., Minier C. and Pellerin J. (2008) Biological indices, energy reserves, steroid hormones and sexual maturity in the infaunal bivalve Scrobicularia plana from three sites differing by their level of contamination. General and Comparative Endocrinology 157, 133-141.

Nishida A., Ohkawa K., Ueda I. and Yamamoto H. (2003) Green mussel Perna viridis $\mathrm{L} .:$ attachment behaviour and preparation of antifouling surfaces. Biomolecular Engineering 2, 381-387.

Norkko J., Pilditch C.A., Thrush S.F. and Wells R.M.G. (2005) Effects of food availability and hypoxia on bivalves: the value of using multiple parameters to measure bivalve condition in environmental studies. Marine Ecology Progress Series 298, 205-218.

Norkko J. and Thrush S.F. (2006) Ecophysiology in environmental impact assessment: implications of spatial differences in seasonal variability of bivalve condition. Marine Ecology Progress Series 326, 176-186.

Norkko J., Thrush S.F. and Wells R.M.G. (2006) Indicators of short-term growth in bivalves: detecting environmental change across ecological scales. Journal of Experimental Marine Biology and Ecology 337, 38-48.

Okumura T., Nagasawa T., Hayashi I. and Sato Y. (2002) Effects of starvation on RNA:DNA ratio, glycogen content, and C:N ratio in columellar muscle of the Japanese turban shell Turbo (Batillus) cornutus (Gastropoda). Fisheries Science 68, 306-312.

Olivar M.P., Diaz M.V. and Chicaro M.A. (2009) Tissue effect on RNA: DNA ratios of marine fish larvae. Scientia Marina 73, 171-182.

Parslow-Williams P.J., Atkinson R.J.A. and Taylor A.C. (2001) Nucleic acids as indicators of nutritional condition in the Norway lobster Nephrops norvegicus. Marine Ecology Progress Series 211, 235-243.

Pease A.K.B. (1976) Studies of the relationship of RNA/DNA ratios and the rate of protein synthesis to growth in the oyster, Crassostrea virginica. Fisheries and Marine Service (Canada) Technical Report 622, 1-77.

Rajagopal S., Venugopalan V.P., Nair K.V.K., van der Velde G., Jenner H.A. and den Hartog C. (1998) Reproduction, growth rate and culture potential of the green mussel, Perna viridis (L.) in Edaiyur backwaters, east coast of India. Aquaculture 162, 187-202.

Rajagopal S., Venugopalan V.P., van der Velde G. and Jenner H.A (2006) Greening of the coasts: a review of the Perna viridis success story. Aquatic Ecology 40, 273-297.
Roddick D., Kenchington E., Grant J. and Smith S. (1999) Temporal variation in sea scallop (Placopecten magellanicus) adductor muscle RNA/DNA ratios in relation to gonosomatic cycles, off Digby, Nova Scotia. Journal of Shellfish Research 18, 405-413.

Rumsey G.L. (1993) Fish meal and alternate sources of protein in fish feed update 1993. Fisheries 18, 14-19.

Segnini de Bravo M.I. (2003) Influence of salinity on the physiological conditions in mussels, Perna perna and Perna viridis (Bivalvia: Mytilidae). Revista de Biologia Tropical 4, 153-158.

Shin P.K.S., Yau F.N., Chow S.H., Tai K.K. and Cheung S.G. (2002) Responses of the green-lipped mussels Perna viridis (L.) to suspended solids. Marine Pollution Bulletin 45, 157-162.

Speekmann C.L., Hyatt C.J. and Buskey E.J. (2006) Effects of Karenia brevis diet on RNA:DNA ratios and egg production of Acartia tonsa. Harmful Algae 5, 693-704.

Sreenivasan P.V., Thangavelu R. and Poovannan P. (1989) Biology of the green mussel, Perna viridis (Linnaeus) cultured in Muttukadu lagoon, Madras. Indian Journal of Fisheries 36, 149-155.

Wagner M., Durbin E. and Buckley L. (1998) RNA:DNA ratios as indicators of nutritional condition in the copepod Calanus finmarchicus. Marine Ecology Progress Series 162, 173-181.

Wang Y., Hu M., Shin P.K.S. and Cheung S.G. (2010) Induction of antipredator responses in the green-lipped mussel Perna viridis under hypoxia. Marine Biology 158, 747-754.

Widdows J. (1978) Combined effects of body size, food concentration and season on the physiology of Mytilus edulis. Journal of the Marine Biological Association of the United Kingdom 58, 109-124.

Wo K.T., Lam P.K.S. and Wu R.S.S. (1999) A comparison of growth biomarkers for assessing sublethal effects of cadmium in a marine gastropod, Nassarius festivus. Marine Pollution Bulletin 39, 165-173.

Wong C.K. and Wong C.K. (2009) Characteristics of phytoplankton community structure during and after a bloom of the dinoflagellate Scrippsiella trochoidea by HPLC pigment analysis. Journal of Ocean University of China (English Edition) 8, 141-149.

Wong W.H. and Cheung S.G. (2001) Feeding rates and scope for growth for green mussels, Perna viridis (L.) and their relationship with food availability in Kat O, Hong Kong. Aquaculture 193, 123-137.

Wright D.A. and Hetzel E.W. (1985) Use of RNA:DNA ratios as an indicator of nutritional stress in the American oyster Crassostrea virginica. Marine Ecology Progress Series 25, 199- 206.

Wu J.F., Chung S.W., Wen L.S., Liu K.K., Chen Y.L., Chen H.Y. and Karl D.M. (2003) Dissolved inorganic phosphorus, dissolved iron, and Trichodesmium in the oligotrophic South China Sea. Global Biogeochemical Cycles 17, 8.1-8.10.

Yang S., Wu R.S.S. and Kong R.Y.C. (2002) Physiological and cytological responses of the marine diatom Skeletonnema costatum to 2,4-dichlorophenol. Aquatic Toxicology 60, 33-41.

and

Yung Y.K., Wong C.K., Broom M.J., Ogden J.A., Chan S.C.M. and Leung Y. (1997) Long-term changes in hydrography, nutrients and phytoplankton in Tolo Harbour, Hong Kong. Hydrobiologia 352, 107-115.

Correspondence should be addressed to:

K.M.Y. Leung

School of Biological Sciences

University of Hong Kong

Pokfulam, Hong Kong, People's Republic of China

email: kmyleung@hku.hk 